\title{
Energy and Resource-Saving Sources of Energy in Small Power Engineering of Siberia
}

\author{
Marina Baranova ${ }^{1, *}$ \\ ${ }^{1}$ Institute of Engineering Systems and Energy FSBEI "Krasnoyarsk SAU", Mira Street, 90, \\ Krasnoyarsk, Russia
}

\begin{abstract}
The sustainable development of distant areas of Siberia is associated with the structures of energy demand and supply, the implementation and promotion of the process of environmentally safe restructuring of the energy supply system. It has been established that suspension coal fuels derived from brown coal, coal mining, coal processing wastes can be used as fuel. The results of experimental and industrial boilers on suspension water coal fuel are presented. The designs of vortex combustion chambers of various powers are developed and tested. The possibility of using coal-enrichment wastes and substandard coals for the production of manure-coal fuel briquettes was studied. It is shown that the strength and thermal power characteristics of briquettes depend on the moisture content and degree of metamorphism of the raw materials. The most effective percentage of the solid phase and manure, as a binder, was determined.
\end{abstract}

\section{Introduction}

A lot of coal-mining and coal-processing enterprises in the sludgeponds and settling basins accumulate a large amount of coal mined (only in the Kuzbass more than 150 million tons), presented in the form of fine coal slurries, the production of which into a transportable and technologically acceptable fuel will not only improve the ecological situation in the coal mining regions, but also to obtain a significant economic effect [1-3].

The use of highly effective methods of mechanical dewatering allows to eliminate the application of thermal drying, which significantly reduces the first cost of the enrichment process and makes it fire and explosion-proof. A closed water-slime cycle without external sludgeponds and settling basins leads to the fact that up to $7 \%$ of processed coal fine waste with a moisture content of $20-45 \%$ and an ash content of $18-60 \%$ is not produced and piled into dumps $[4,5]$.

As a result, a by-product of enrichment appears - filter cake, high moisture and ash content and small particle size of which do not allow it to be sent to consumers. The utilization of such wastes is a vital task, which can be solved by creating a coal-water fuel from coal-enrichment sludge.

The purpose of this work is to demonstrate the possibility of using locally available and

${ }^{*}$ Corresponding author: marina60@mail.ru 
inexpensive resources as a source of energy.

\section{Results and discussion}

Water-coal suspensions. The production of suspension water-coal fuels (WCF) is one of the developed and applied technologies. This technology allows to create efficient and reliable systems for the production of high-quality heat energy in the close proximity to local consumers, taking into account their specific needs. Investment attractiveness is due to the compactness and high environmental friendliness. To burn such fuels effectively, the development of special technologies and technical means is required. In this case, the technology of low-temperature vortex combustion in adiabatic combustion chambers is successfully used, such chambers are either integrated into the combustion chamber of existing or newly developed boilers, or installed next to the operating boiler [6-8]. At the same time, the designs of the combustion chambers must take into account not only the low reactivity of the WCF, but also the fact that when spraying WCF the flame length reaches $2.5 \mathrm{~m}$ and more, and the time for the WCF solid phase particles in the combustion chamber is from $1 \mathrm{~s}$ to $4 \mathrm{~s}$. The heat generators work experience has shown that with a heat output of more than 2.0 - (3.0) megaW, the combustion chamber is built into the furnace space of the boiler without increasing its dimensions. At a heat output of less than 2.0 - (3.0) megaW, the installation of a stand-alone (remote) combustion chamber is required [7-9].

Below are the results of the experimental and industrial boilers work on suspension water-coal fuel and local brown coals. The CJSC «SPE Sibecotechnika» has developed and tested the design of vortex combustion chambers of various power (Table 1).

Table 1. Characteristics of the operation of heat generators

\begin{tabular}{|l|c|c|c|}
\hline \multicolumn{1}{|c|}{ Indicator name } & \multicolumn{3}{|c|}{ Technological Complexes } \\
\cline { 2 - 4 } & $\begin{array}{c}\text { Technological } \\
\text { complex KuzSTU, } \\
\text { Kemerovo }\end{array}$ & $\begin{array}{c}\text { Heat generator in } \\
\text { SibEME SD, } \\
\text { Krasnoobsk, } \\
\text { Novosibirsk region }\end{array}$ & $\begin{array}{c}\text { Boiler house in } \\
\text { Cherepanovo, } \\
\text { Novosibirsk region }\end{array}$ \\
\hline $\begin{array}{l}\text { Heating capacity, Gcal } \\
/ \mathrm{h}\end{array}$ & 0.05 & 0.25 & 0.5 \\
\hline Fuel consumption, 1/ $\mathrm{h}$ & $120 \div 130$ & 55 & $110 \div 220$ \\
\hline $\begin{array}{l}\text { Temperature in the } \\
\text { furnace, }{ }^{0} \mathrm{C}\end{array}$ & $950 \div 1050$ & 950 & $950 \div 1050$ \\
\hline & Characteristics of WCF, burned in heat generators \\
\hline Moisture, general, \% & $40 \div 42$ & $42 \div 43$ & $38 \div 43$ \\
\hline $\begin{array}{l}\text { Ash content (on dry), } \\
\%\end{array}$ & $26 \div 45$ & $8.2 \div 8.5$ & $30 \div 45$ \\
\hline $\begin{array}{l}\text { The yield of volatiles, } \\
\%\end{array}$ & $23.0 \div 41.2$ & $42.3 \div 43.1$ & $6 \div 42$ \\
\hline Particle size, micron & $0 \div 500$ & $0 \div 500$ & $0 \div 500$ \\
\hline
\end{tabular}

As a raw material, both coal concentrate (heat generator in SibEME SD of Krasnoobsk, Novosibirsk Region) and coal slurries were used. The results of pilot tests of the developed heat generators have shown that even at low values of the lowest calorific value $(2500 \mathrm{kcal}$ $/ \mathrm{kg}$ ) of WCF from different grades of coal, it is possible to obtain the efficiency value more than $80 \%$. At the same time (first cost) 1 Gcal is reduced by $30-300 \%$ in comparison with burning of grade coal or liquid petroleum fuel [10]. 
At the present time in Barnaul a boiler plant has been set up (LLC «ProEnergoMash») for the production of specialized boilers with the «Tornado» vortex combustion system, which allows to burn efficiently local, including ballasted, fuels.

On the territory of the Krasnoyarsk Region there are quite a lot of different scale of brown coal deposits. Brown coals, because of the low degree of metamorphism, lose their energy properties during storage, and also differ in their low net calorific value. To determine the possibility of the boiler KV-1,2-105 ShpVT with a furnace «Tornado» produced by LLC «ProEnergoMash» on the brown coal of mine «Chulymsky» (Krasnoyarsk Region), special tests were carried out. The coal had the following characteristics: humidity - 43.2\%; ash content - 11.3\%; net calorific value $-2820 \mathrm{kcal} / \mathrm{kg}$; poured density $-868 \mathrm{~kg} / \mathrm{m} 3$. The test results are shown in Table 2.

Table 2. Test results.

\begin{tabular}{|c|c|c|c|}
\hline \multirow[t]{2}{*}{ Parameter name } & \multirow{2}{*}{$\begin{array}{c}\text { Unit of } \\
\text { measure }\end{array}$} & \multicolumn{2}{|c|}{ Numeric value } \\
\hline & & diapason & average \\
\hline Total amount of heat produced & Gcal & - & 0,350 \\
\hline Outgoing gases temperature & ${ }^{\circ} \mathrm{C}$ & $41-87$ & 64 \\
\hline $\begin{array}{l}\text { The temperature of the hot layer above the grate } \\
\text { in the furnace on the grate }\end{array}$ & ${ }^{\circ} \mathrm{C}$ & $1000-1100$ & 1050 \\
\hline The rarefaction in the furnace & $\mathrm{mm} \mathrm{WG}$ & $1,5-3,0$ & 2,4 \\
\hline $\begin{array}{l}\text { Composition of flue gases behind the boiler: } \\
\mathrm{CO}_{2} \\
\mathrm{O}_{2} \\
\mathrm{CO} \\
\mathrm{NO} \\
\mathrm{SO}_{2}\end{array}$ & $\begin{array}{c}\%, \\
\% \\
\mathrm{mg} / \mathrm{m}^{3} \\
\mathrm{mg} / \mathrm{m}^{3} \\
\mathrm{mg} / \mathrm{m}^{3}\end{array}$ & & $\begin{array}{c}14 \\
13 \\
185 \\
110 \\
320\end{array}$ \\
\hline Heat of fuel combustion & $\mathrm{kcal} / \mathrm{kg}$ & & 2820 \\
\hline \multicolumn{4}{|c|}{ The control combustion conditions } \\
\hline Weight of coal supplied & $\mathrm{kg}$ & & 150 \\
\hline Quantity of slag & $\mathrm{kg}$ & & 17,5 \\
\hline Quantity of fly ash & $\mathrm{kg}$ & & 1,5 \\
\hline
\end{tabular}

During the tests in selected calculated stationary modes it was determined that:

- the boiler works steadily on non-calculated fuel, the average temperature of the layer is $1000-1100^{\circ} \mathrm{C}$;

- possible steady combustion in the combustion chamber at modes from $100 \%$ to $25 \%$ of the load and manual regulation;

- removal from the combustion chamber is shallow, insignificant, there are no visible smoke emissions from the chimney;

- coefficient of excess air behind the boiler is 1.4-1.6;

- the temperature behind the boiler does not exceed $120^{\circ} \mathrm{C}$.

Fuel briquettes. The technology for producing coal briquettes using pig manure as binders has been known for a long time. In Siberia and the Krasnoyarsk Region, as in all coal-mining regions, there is a problem of efficient use of substandard coal and coal processing waste. In addition, at the present time in the region for an average of 858 thousand tons of manure per year, the utilization of which is a big problem [10-12].

During the fuel briquettes burning the coefficient of usefulness of coal chemical energy is $70-80 \%$. The advantage is explained by the fact that the flops of unburned coal are 
practically completely excluded from the grate; decreases physical and chemical underburning due to better conditions for air access to the surface of briquettes; the content of carbon monoxide and soot in flue gases decreases [10]. In the course of the work, the influence of the raw material characteristics on the strength and heat power characteristics of fuel briquettes from sub-standard coals and manure was determined.

As a raw materials were used: pig manure (LLC «Emelyanovskoye»), coals of B2 grade Berezovskoye deposit and D grade Balakhtinskoye deposit, coarse-grained and fine-grained sludge («Polosukhinskaya» mine, Kemerovo region). The characteristics of the starting materials and the grain-size classification are presented in Tables 3 and 4.

During the experimental work, the composition of the mixture was calculated in accordance with GOST 27313-95. Next, the starting components were mixed in a mixer for 7 minutes. The mixture was pressed on a hydraulic press with a pressure of 300 to $500 \mathrm{kgf} /$ $\mathrm{cm}^{2}$ in a matrix having 20 molds with a diameter of $35 \mathrm{~mm}$ each.

Table 3. Characteristics of raw materials.

\begin{tabular}{|l|c|c|}
\hline \multicolumn{1}{|c|}{ Component } & Humidity, \% & Ash content, $\%$ \\
\hline Pig manure & 80,2 & 5,8 \\
\hline Coal of B2 grade & 21,9 & 8,7 \\
\hline Coal of D grade & 3,7 & 12,3 \\
\hline Coarse-grained sludge & 14,5 & 14,7 \\
\hline Fine-grained sludge & 34,6 & 27,8 \\
\hline
\end{tabular}

Table 4. Granulometric composition of starting materials.

\begin{tabular}{|l|c|c|c|}
\hline \multirow{2}{*}{ Class, mm } & \multicolumn{3}{|c|}{ Content, \% } \\
\cline { 2 - 4 } & Coal of D grade & Coal of B2 grade & Fine-grained sludge \\
\hline+3 & 2,1 & - & - \\
\hline $1-3$ & 21,1 & - & - \\
\hline $0,63-1$ & 12,0 & 0,1 & 0,7 \\
\hline$-0,63$ & 64,8 & 99,9 & 99,3 \\
\hline Итого & 100 & 100 & 100 \\
\hline
\end{tabular}

The received briquettes were analyzed for moisture content in accordance with GOST 27314-91, ash content according to GOST 11022-95. Drying of briquettes took place at $100^{\circ}$ and $150^{\circ} \mathrm{C}$. The received briquettes were tested for drop resistance according to GOST 21289-75. The dried briquettes were burned in a laboratory installation.

The research of the influence of the quantitative composition of the initial raw components in briquettes on their quality have been carried out. On the basis of these studies, the optimal ratios of the initial components in the briquette mixture were revealed. Briquettes with a manure ratio were obtained: coal in $\%-5: 95 ; 10: 90 ; 15: 85 ; 20: 80 ; 25: 75$; 30:70. During the experimental work, it was established that briquettes from coal grade D at all ratios do not retain their shape when processed in a press at a pressure of 250 to 500 $\mathrm{kgf} / \mathrm{cm}^{2}$. Briquettes from brown coal and scraps are more stable when processed with a pressure of 300 to $500 \mathrm{kgf} / \mathrm{cm}^{2}$ and retain their shape after drying and drop resistance testing. The dropping strength was basically $80-90 \%$ for all of the above ratios.

The coal compositions of different stages of metamorphism and coal processing waste are studied in the process of obtaining briquettes. It is established that the best compositions, taking into account the strength of the obtained briquettes, are briquettes with a coal ratio of grade D - up to $10 \%$ : grade B2 - from $60 \%$ : manure with a moisture content of $72 \%$ - not more than $30 \%$. It should be noted that the production of briquettes based on sludges, i.e. waste of coal mining, practically does not cause technological and technical 
problems. Heating the initial mixture up to $50-60{ }^{\circ} \mathrm{C}$ leads to an improvement in the strength characteristics of briquettes from all coals.

Analysis of the data on the kinetics of briquette drying showed that at a humidity of $36.8 \%$ and a temperature of $100{ }^{\circ} \mathrm{C}$, the drying time is 78 minutes, at $150{ }^{\circ} \mathrm{C}-52$ minutes, that is, a reduction in drying time of about $27 \%$; at a ratio of $20 \%$ of a fine-grained sludge: $80 \%$ of a coarse-grained sludge with a moisture content of $15.3 \%$ and a temperature of 100 ${ }^{\circ} \mathrm{C}$, the drying time is 43 minutes; at $150{ }^{\circ} \mathrm{C}, 27$ minutes, that is, a reduction in drying time of $32.5 \%$. Residual humidity of briquettes from sludges after drying in the air for 14 days amounted to $\mathrm{W}_{\mathrm{t}}^{\mathrm{r}}=1.9 \%$; after the air drying for 3 days, the manure-coal briquettes amounted to $\mathrm{W}_{\mathrm{t}}^{\mathrm{r}}=36.8 \%$. The weight of briquettes averaged 17.3-18.1 grams.

During the work, calculations were made of the net calorific value. It is established that for briquettes (manure (30\%): coal DR (70\%) with a humidity of 30\%, the lowest calorific value is $3000 \mathrm{kcal} / \mathrm{kg}$; for briquettes after drying, manure $(30 \%)$ : coal B2 $(70 \%)$ at a humidity of $36,8 \%$ - $2676 \mathrm{kcal} / \mathrm{kg}$; for briquettes manure $(30 \%)$ : fine-grained sludge $(70 \%)$ with a moisture content of $52.1 \%-2031 \mathrm{kcal} / \mathrm{kg}$; for briquettes fine-grained sludge (20\%): coarse-grained sludge $(80 \%)$ at a humidity of $10 \%$, the lowest calorific value is $6050 \mathrm{kcal} / \mathrm{kg}$; for briquettes fine-grained sludge (30\%): coarse-grained slurry $(70 \%)$ with a humidity of $10 \%-6000 \mathrm{kcal} / \mathrm{kg}$.

\section{References}

1. BP Statistical Review of World Energy (British Petroleum, 2013)

2. V. G. Lury, A.N. Pankratov, Coal, 11, 36 (2013)

3. A.V. Papin, A.V. Nevedrov, A.I. Sechin, Polzunovsky vestnik, 3, 220 (2014)

4. C.H. Kuzmin, R. L. Isyemin, V. V. Konyakhin, E.V. Budkova, A.B. Mikhalev, Coal, 5:937, 51 (2004)

5. Huang Bo, Zhao Yu-feng, Gong Xu-wen, J. Clean coal technology, 6, 23 (2011);

6. V. I. Fedyaef, V. I. Murko, H. L. Inetdinof, M. P. Baranova, Clean Coal Technology, 6, 43 (2011)

7. V. I. Murko, V. N. Delyagin, N. M. Ivanov, V. Ya. Batishchev, V. I. Bocharov, I. Shcheglov, V. I. Fedyaev, V. I. Karpenok, Polzunovsky vestnik, 2:1, 239 (2011)

8. V.I. Murko, V.I. Fedyaev, H.L. Aynetdinov, M.P. Baranova, The 17th International Coal Preparation Congress, 679 (2013)

9. V. I. Murko, V. N. Delyagin, M.P. Baranova, S. N. Shakhmatov, Vestnik of KRASGAU, 11, 103 (2015)

10. A.N. Koshka, In: Waste management - a basis of restoration of ecological equilibrium in Kuzbass, 136 (2008)

11. L.A. Antonenko, E.V. Pilipenko, K.I. Domnin, E.P. Volynkina, A.E. Anikin, Science and youth: problems, searches, decisions, 188 (2012) 
